\title{
HUMORAL AND CELL FACTORS OF NATURAL RESISTANCE IN THE ANIMALS OF LOCAL BREEDS IN SPECIFIC ENVIRONMENTAL CONDITIONS OF THE TYVA REPUBLIC
}

\author{
R.B. CHYSYMA ${ }^{1}$, Yu.N. FEDOROV 2 , E.Yu. MAKAROVA ${ }^{1}$, G.D. KUULAR ${ }^{3}$
}

\begin{abstract}
${ }^{1}$ Tuva Research Institute of Agriculture, Federal Agency of Scientific Organizations, 4, ul. Bukhtueva, Kyzyl, Tuva Republic, 667005 Russia, e-mail chysyma@mail.ru;

${ }^{2}$ All-Russian Research and Technological Institute of Biological Industry, Federal Agency of Scientific Organizations, 17, pos. Biokombinata, Shchelkovskii Region, Moscow Province, 141142 Russia, e-mail fun181@mail.ru;

${ }^{3}$ Tuva State University, 36, ul. Lenina, Kyzyl, Tyva Republic, 667000 Russia, e-mail kuularg@mail.ru Received August 10, 2015
\end{abstract}

\section{Abstract}

Humoral and cellular factors of natural resistance of animals are represented by diverse proteins, peptides, lysosomal enzymes, and immunocompetent cells contained in blood. The natural resistance factors possessing antimicrobial properties additionally activate the other humoral and cellular immunity mechanisms. The natural resistance system formed during the process of evolution and microevolution of domesticated animals determines their fitness to biotic and abiotic stresses caused by the action of pathogens, unfavorable natural-climatic conditions that is most importantly for animals under all-year-round pasture keeping conditions. The landscapes of the Republic of Tuva are mountainous; this is a territory with sharply continental climate, frosts of down to $-50{ }^{\circ} \mathrm{C}$ in winters, cool summer in highlands and hot in depressions. Nevertheless, the region is thought favorable for rearing native breeds of horses (Equus ferus caballus), sheep (Ovis aries), goats (Capra aegagrus hircus), and highland yaks (Poephagus grunniens), which are well fit to such complex conditions. Of the species listed, only the yaks were earlier studied with regard to evaluating the state of their cellular and humoral immunity. A comparative study on natural resistance parameters in native Tuvinian horses, highland yaks, Tuvinian short-fat-tailed sheep and goats of Tuvinian population was performed by us for the first time. The evaluation of humoral and cellular factors of natural resistance revealed specific distinctions. Thus, the native Tuvinian horses are superior to goats of Tuvinian population and Tuvinian short-fat-tailed sheep in phagocytosis activity as much as 1.38 and 1.43 times, respectively $(\mathrm{P}<0.001)$. The maximum phagocytal index was observed in horses of native breeds $(\mathrm{P}<0.001$ and $\mathrm{P}<0.01)$. Highland yaks showed parameters of phagocytosis activity and phagocytal index higher than those in goats and sheep $(\mathrm{P}<0.001)$. The determination of the content of lysosomal-cationic proteins showed interspecific distinctions, which were most expressed in native Tuvinian horses and highland yaks. Concentration of lysosomal-cationic proteins in blood serum of horses and yaks was characterized by the maximum values, while this index in goats and sheep was lower $(\mathrm{P}<0.001)$. Positive correlation $(r=0.86-0.98)$ between phagocytosis activity, phagocytal index and the level of lysosomal-cationic proteins was found to be in the all animals studied. It should be noted that the data from available literary sources on such a relationship in agricultural animals are extremely limited. We also revealed interspecific diversity in the content of immunoglobulins of primary isotypes (IgG, $\operatorname{IgM}, \operatorname{IgA})$, the high values of which were observed in goats and sheep.

Keywords: natural resistance, local Tuva horses, high-mountain yak, Tuva goat population, Tuva short-fat-tailed sheep.

Natural resistance is a genetically inherited capability of withstanding adverse environmental agents. Humoral and cellular factors of natural resistance of animals are represented by diverse proteins, peptides, and immunocompetent blood cells. Due to antimicrobial properties, they are capable of activating other humoral and cellular immunity mechanisms. The macroorganism capability of withstanding biotic and abiotic stressors, including pathogens, in mainly determined by the activity of the humoral and cellular defense factors. The mechanisms of resistance may be static or dynamic, specific or non-specific; when infection developing, they can be realized before its onset or as a response to it, and may 
result in the destruction of the pathogen or in the limitation of its ability to affect the host. In other words, to realize the natural resistance mechanisms, various adaptive reactions of cellular and humoral nature formed during the process of evolution are required, which is the reason of the fundamental interest in the problem [1].

At the same time, natural resistance is important practically, as the health, reproductive function, productive longevity of livestock and, ultimately, the profitability of the livestock depend on the capability of specimens of counteracting aggressive biotic and abiotic agents. Adaptation to specific climatic conditions depends on the natural resistance systems formed in evolution and micro-evolution, which is especially important for the year-round grazing species and breeds, and also if the growing with year-round grazing is possible considering the local conditions. Moreover, the farm animal welfare has become relevant in relation to the species that have been traditionally grown indoors. A positive impact of the close to natural conditions on the physiological status, resistance to pathologies [2-4] and, as a consequence, on the production of livestock is discussed, although the associated risks, the threat of infection in particular, are recognized $[5,6]$.

Nevertheless, the Tyva region is thought favorable for rearing local breeds of horses, sheep, goats, and highland yaks. These animals are amazingly persistent and tenacious to survive under the severe conditions of the region, and well adapted for year-round grazing [7]. To solve the practical problems of health, breeding and improvement of these animals, it is important to take into account their physiological potential, including natural resistance. To date, the immune status features have been defined in the majority of farm animal breeds, and the methods for its estimation have been suggested [8-11]. However, the natural resistance of the local breeds and indigenous populations under the extreme conditions of the Tyva Republic is poorly studied, with greater attention paid to yaks' physiological and biochemical status as influenced by specific regional climatic and ecological features [12].

The purpose of this work was to characterize the natural resistance of local horse breeds, native sheep and goat breeds, and highland yaks under the conditions of the Republic of Tyva. Research in these aspects reported herein has been performed by us for the first time.

Technique. The study was conducted in 2013-2014 in the basic enterprises of the Tyva Research Institute of Agriculture, the «Bai-Tal» and «Malchyn»(Bai-Taiga and Mongun-Taiga regions, Republic of Tyva). The Tuvinian population of wool goats (Capra aegagrus hircus), short-fat-tailed sheep (Ovis aries), native breed horses (Equus ferus caballus), and Tuvinian Sarlyk highland yaks (Poephagus grunniens) have been surveyed. The animals were grouped based on their age, physiological conditions, body weight, and productivity. The animals were kept at pastures year-round.

The phagocytic activity (PA) of neutrophils was estimated with a suspension of Escherichia coli overnight culture. Using a Biolar IDP5AZ (Zeiss AG, Germany) light microscope, we calculated phagocytic indices (PI) as an average number of microbial cells absorbed by an active neutrophil, and the percentage of phagocytosis as a percentage of neutrophils capable of absorbing microorganisms [13]. The blood granulocyte saturation with cationic protein was estimated based on the lysosomal cationic test (LCT, a semi-quantitative method for detecting cationic protein-containing granules in neutrophils) by microscopy of the blood smears stained with bromophenol blue followed by calculation by AstaldiVergathe formula; lysosomal cationic protein (LCP) granules were calculated according to V.E. Pigarevsky [14] using LCT. Concentrations of blood serum G, M and A immunoglobulins (Ig) were measured by radial immunodiffusion (RID) 
with known monospecific antisera and monoclonal antibodies against each immunoglobulin isotype and with standard animal sera with the known content of the relevant immunoglobulin isotype [15].

Data were analyzed statistically using Microsoft Excel and SNEDECOR V4 software [16].

Results. In the Republic of Tyva, native breeds graze on alpine pastures in the warmer months; starting from September, they are gradually herd in a mountain gorges closer to the wintering grounds. In winter and spring (until April), the animals are at the winter pastures that are mainly located in the mountains of medium height, where the pasture in this period is only possible in the areas with low snow cover. To feed the weak and sick animals during the cold season, the reserve stocks of fodder are formed at the pastures, the young animals and the breeding stock are additionally given hay and salt lick.

The protective leukocyte function is the phagocytosis-based, meaning the leukocyte capability of recognizing, absorbing, killing and digesting foreign cells [17]. The PA value makes it possible to estimate the neutrophil reserves for the absorption and neutralization of microbes. We identified considerable speciesspecific differences in this parameter between native breeds of horses, sheep, goats, and highland yaks (Table 1). Thus, the native Tuvinian horses were superior to the goats of Tuvinian population and Tuvinian short-fat-tailed sheep in PA as much as 1.38 times and 1.43 times, respectively $(\mathrm{P}<0.001)$. The interspecific differences in PI were found as well, in particular, the maximum values were observed in horses of native breeds compared to the sheep and goats $(\mathrm{P}<0.001$ $0.01)$. The PA of neutrophils and PI were slightly lower in yaks versus horses but significantly higher compared to goats and sheep $(\mathrm{P}<0.001)$. The lowest phagocytic activity (38.6 and $37.3 \%)$ and phagocytic index (4.0 and $3.8 \mathrm{mi}-$ crobial cells per neutrophil) were found in goats and sheep $(\mathrm{P}<0.001)$.

1. Phagocytosic activity (PA), phagocytal index (PI) and lysosomal-cationic protein content in neutrophils (LCP) in native Tuvinian breeds $(X \pm X$, SUE «BaiTal», SUE «Malchyn», Bai-Taiga and Mongun-Taiga districts, Republic of Tuva)

\begin{tabular}{l|c|c|c|c}
\hline \multicolumn{1}{c|}{ Parameter } & Goats & \multicolumn{1}{c|}{ Sheep } & Horses & Highland yaks \\
\hline PA, \% & $38.60 \pm 0.43$ & $37.30 \pm 0.42$ & $53.50 \pm 0.82$ & $49.60 \pm 0.32$ \\
PI, microbial cells/neutrophil & $4.00 \pm 0.08$ & $3.80 \pm 0.09$ & $4.60 \pm 0.11$ & $4.20 \pm 0.04$ \\
LCP, common units & $1.14 \pm 0.04$ & $1.00 \pm 0.04$ & $1.71 \pm 0.02$ & $1.61 \pm 0.01$ \\
\hline
\end{tabular}

The presence of non-enzyme cationic proteins in neutrophilic and eosinophilic granulocyte lysosomes was detected in the lysosomal cationic test, the results of which are considered as one of the main indicators of neutrophil bactericidal activity and of the natural resistance of the body. Granulocytes possess proteolytic and biocidal properties, and the content of their granules and the intensity of staining can characterize the oxygen-dependent neutrophil biocidal system. Its effects are based on the breach of the structure and function of microbial cell membranes. The lysosomal antimicrobial cationic proteins belong to a special class of physiologically active substances that have arisen in the evolution of biochemical mechanisms of antimicrobial protection [17].

Estimation of LCP amount in native horse, sheep, goat, and highland yak breeds demonstrated interspecific differences as well, most pronounced ones found in the native breed horses and highland yaks with the highest values of this parameter versus goats and sheep in which it was significantly lower $(\mathrm{P}<0.001)$. A positive correlation $(r=0.86-0.98)$ between phagocytosis activity and LCP was found in all native breeds. Probably, phagocytosis intensified with an increase in the LCP amount in all specimens examined. Published data on this association in farm animals are still extremely poor, although there are re- 
ports on a broad spectrum of the lysosomal cation proteins' activity and their involvement into numerous protective and adaptive processes (i.e., cell permeability, chemotaxis, opsonization, phagocytosis and inflammation) [18, 19].

The informative characteristics of the state of natural resistance and immune status include the quantitation of blood serum immunoglobulin isotypes $\mathrm{IgG}, \mathrm{IgM}$, and $\mathrm{IgA}$. These parameters are the most important criterion in the evaluation of the functional activity of B-cell immune system and in the diagnosis of various immunodeficiencies [20, 21].

$\mathrm{IgG}$ plays the greatest role in the protection against infections. These immunoglobulins are involved in the neutralization of viruses, bacteria, and toxins and prevent the development of infection [22-24]. The greatest IgG serum concentration was observed in goats $(23.05 \pm 0.17 \mathrm{mg} / \mathrm{ml})$ which was higher compared to sheep and yaks by 4.40 and $9.02 \%$, respectively $(\mathrm{P}<0.001)$. The lowest $\operatorname{IgG}$ level observed in highland yaks was 2.08 and $1.08 \mathrm{mg} / \mathrm{ml}$ less than that of goats and sheep $(\mathrm{P}<0.001)$ (Table 2$)$.

2. Different immunoglobulin classes in the blood serum of native Tuvinian breeds $(X \pm X$, «Bai-Tal» and «Malchyn» enterprises, Bai-Taiga and Mongun-Taiga regions, Republic of Tyva)

\begin{tabular}{l|c|c|c}
\hline Concentration, $\mathrm{mg} / \mathrm{ml}$ & Goats & Sheep & Highland yaks \\
\hline IgG & $23.05 \pm 0.17$ & $22.05 \pm 0.18$ & $20.97 \pm 0.53$ \\
IgM & $2.28 \pm 0.16$ & $3.07 \pm 0.05$ & $2.54 \pm 0.11$ \\
IgA & $0.81 \pm 0.02$ & $0.83 \pm 0.02$ & $0.22 \pm 0.01$ \\
\hline
\end{tabular}

$\mathrm{M}$ isotype immunoglobulins are synthesized by plasma cells in the secondary lymphoid organs. This is the main class of antibodies that play an important protective role in the earlier stages of antigen exposure and that are produced in the primary immune response. Although IgM is synthesized in small quantities, it is more effective in activating complement, opsonization, virus neutralization and agglutination compared to IgG [22-24]. In our studies, a significantly high $\operatorname{IgM}$ concentration was found in sheep when the same parameter in yaks and goats was exceeded by 25.7 and $17.3 \%$, respectively $(\mathrm{P}<0.001)$.

IgA is the main immunoglobulin of mucosal secretions and the main factor of their specific protection [22-24]. The functions of serum IgA, represented mainly by the monomeric form is less clear due to the fact that it is poorly involved in complement activation, does not bind complement by the classical type, is not capable of precipitating soluble antigens, and agglutination and lyses of corpuscular antigens. Its biological role in the body is determined by the interaction of all immunoglobulin isotypes. Quantitatively, it is much inferior to other isotypes. However, the species features were identified in this parameter as well. Thus, IgM concentration did not differ in sheep and goats, was 3.7 times higher compared to highland yaks $(\mathrm{P}<0.001)$, and amounted to $0.83 \pm 0.02$ and $0.81 \pm 0.02 \mathrm{mg} / \mathrm{ml}$, respectively.

In general, an increase in the cell-mediated immune activity in Tuvinian horses and highland yaks and an increase in antibody-mediated humoral immunity in native goat and sheep breeds have been detected.

Thus, our study made it possible to describe the main features of natural resistance and its interspecies differences in local horse breeds, native sheep and goat breeds, and highland yaks under the specific ecological conditions of the Republic of Tyva. A positive correlation $(r=0.86-0.98)$ between phagocytosis activity, phagocytic index and the level of lysosomal-cationic proteins was found in all the species studied. Compared to goats and sheep, native horse breeds and yaks had greater phagocytosis activity and phagocytic index, as well as the increased amount of lysosomal cationic proteins. The species diversity for immunoglobulin profile observed in the studied animal groups was manifested, in par- 
ticular, in the greatest levels of blood serum immunoglobulins in the Tuvinian goat population and in the Tuvinian short-fat-tailed sheep breed. The features of natural resistance found out in native breeds can be attributed to the speciesspecific differences in the functional activity of homeostasis regulatory systems formed in the course of evolution under extreme climatic conditions.

\section{REFEREN CES}

1. B e r to k L. Natural immunity. Elsevier-Press, The Netherlands, 2010.

2. Tham sborg S.M. Organic farming in the Nordic countries - animal health and production. Acta Vet. Scand., 2001 Suppl, 95: 7-15 (doi: 10.1186/1751-0147-43-S1-S7).

3. Sørensen J.T., Edwards S., Noordhuizen J., Gunnarsson S. Animal production systems in the industrialised world. Rev. Sci. Tech., 2006, 25(2): 493-503.

4. Me n ch J.A., S u m n e r D.A., Ros e n-Molina J.T. Sustainability of egg production in the United States - the policy and market context. Poult. Sci., 2011, 90(1): 229-240 (doi: 10.3382/ps.2010-00844).

5. Kijlstra A., Eissen O.A., Cornelissen J., Munniksma K., Eijck I., Kortb e e k T. Toxoplasma gondii infection in animal-friendly pig production systems. Invest. Ophthalmol. Vis. Sci., 2004, 45(9): 3165-3169.

6. Kijlstra A., Me e rburg B.G., B os A.P. Food safety in free-range and organic livestock systems: risk management and responsibility. J. Food Prot., 2009, 72(12): 2629-2637.

7. Chys y ma R.B., M a k a ro v a E.Yu. Sibirskii vestnik sel'skokhozyaistvennoi nauki, 2013, 5: 39-43.

8. Fedorov Yu.N. Faktory immunologicheskoi zashchity $u$ ovets $v$ sisteme mat'-plodnovorozhdennyi. Doktorskaya dissertatsya [Factors of immune defense in sheep ewe-foetusnewborn lamb. DSc Thesis]. Moscow, 1984.

9. F e d o r o v Yu.N. V sbornike: Strategiya razvitiya zhivotnovodstva Rossii - XXI vek [In: Strategy for animal husbandry in Russia in XXI century]. Moscow, 2001: 337-346.

10. F e d o r o v Yu.N. Sel'skokhozyaistvennaya biologiya [Agricultural Biology], 2004, 2: 3-9.

11. N e u st ro e v M.P., M l y s h e va V.I. Otsenka estestvennoi rezistentnosti loshadei (metodicheskie rekomendatsii) [Estimation of natural resistance in horses: recommendations]. Novosibirsk, 1995.

12. Ch y s m a R.B. Sel'skokhozyaistvennaya biologiya [Agricultural Biology], 2005, 4: 11-13.

13. Emel'y a nenko P.A., Gryzlova O.N., D e nis e nko V.N. et al. Metodicheskie rekomendatsii po testirovaniyu estestvennoi rezistentnosti telyat [Manual for estimation of natural resistance in calves]. Moscow, 1980.

14. Pig a revski i V.E. Lizosomal'no-kationnyi test (metodicheskie rekomendatsii) [Lysosome cation test: guideline]. Moscow, 1978.

15. Manchini G., Carbo nara A.O., Here mans I.P. Immunochemical quantitation of antigens by single radial immunodiffusion. Immunochemistry, 1965, 2(3): 235-254.

16. S o r o k i n O.D. Prikladnaya statistika na komp'yutere [Applied statistics on PC]. Novosibirsk, 2008.

17. $\mathrm{K} h$ a it o v R.M. Immunologiya. Moscow, 2015.

18. B e z ruk ova E.V., S i mbi rt se v A.S., K h me l' nit sk a y a N.M. Tsitokiny $i$ vospalenie, 2013, 12(1-2): 137-142.

19. Berezhnaya N.M., Chekhun V.F., Sepiashvili R.I. Allergologiya $i$ immunologiya, 2005, 6(1): 38-49.

20. K h a it o v R.M., P in e g in B.V., Y a rili in A.A. Rukovodstvo po klinicheskoi immunologii: diagnostika zabolevanii immunnoi sistemy [Manual for clinical immunology: diagnostics of immune diseases]. Moscow, 2009.

21. P e t r o v R.V., K h a it o v R.M., P i n e g i n B.V. Immunologiya, 1997, 4: 4-7.

22. T i z a rd I.R. Veterinary immunology. Elsevier-Press, The Netherlands, 2013.

23. Y a rili in A.A. Immunologiya [Immunology]. Moscow, 2010.

24. Gerald N.C., Robin M.Y. Basis veterinary immunology. University Press of Colorado, Boulder, 2014. 